\title{
The Reality of Applying Knowledge Management Practices and Its Impact on Achieving the Quality of Higher Education in Jordan
}

\author{
Dr. Mohammad Niqresh \\ Assistant Professor, \\ Princess Alia University College, \\ Al Balqa Applied University, \\ P.O. B. 206, Salt 19117, Jordan
}

DOI: https://doi.org/10.36941/jesr-2021-0oo2

\begin{abstract}
This research aims to identify the reality of applying knowledge management practices and reveal their impact on achieving the quality of higher education in Jordan, and to identify the concept of knowledge management and the quality of higher education, and uncover knowledge management practices, and determine the components of applying knowledge management in higher education institutions. To achieve the research objectives, the researcher used the descriptive and analytical approach, relying on the questionnaire as the main tool for collecting research data. The research was applied to a sample consisting of (142) workers and those in charge of the educational process at Al-Balqa Applied University, who were chosen randomly. Among the most prominent results of this research is that there is an effect of knowledge management on higher education quality at Al-Balqa Applied University at the significance level $(\alpha=0.05)$. As the results showed, one of the essential practices of knowledge innovation and creativity is that knowledge management encourages brainstorming to create new ideas and reveal tacit knowledge. One of the most important practices of applying the knowledge is that the university conducts tests on knowledge before applying it, while the essential practice of storing and distributing knowledge is that the university has many methods and means used to preserve knowledge. In light of the study results, the research recommends the need to pay attention to those in charge of the educational process and those working in it, support them and develop their capabilities, and work to implement the knowledge that it possesses through a specialized work team, and the necessity for the knowledge management to work on developing the creative vision of the employees at the university.
\end{abstract}

Keywords: Knowledge Management, Practices, Quality, Higher Education, Jordan

\section{Introduction}

In the late twentieth century and the beginning of the twenty-first century, the world witnessed a technological and knowledge revolution, and this revolution covered many fields, including the field of public administration, such as restructuring, re-engineering processes, total quality management, and developing the concept of knowledge management. Where the concept of knowledge management is one of the essential concepts that must be focused on, it works to put the skills and knowledge that are acquired in the hands of the employees at the appropriate time, place, and image, and also contribute to achieving the highest levels of achievement (Hammoud, 2015). 
Knowledge is one of the concepts that have been used since ancient times in the world of thought and philosophy, and with the development of time, this concept has evolved to become broader and includes many aspects that overlap with the new administrative methods, where knowledge has become a significant element in the strategies of organizations and business enterprises. Knowledge management has become a vital concept in the field of management. The importance of knowledge management in business enterprises lies in meeting many goals and objectives; such as supporting the administration in achieving the process of intellectual renewal, building and enabling the capabilities necessary to deal with developments, and raising the identification and prediction of change problems early that allows the administration to prepare to face them (Al-Baqour, 2016).

Knowledge management is one of the most prominent administrative concepts that constitute the group of processes that contribute to obtaining knowledge, its formation, selection, organization, distribution, and use in business organizations. Knowledge management also contributes to transferring meaningful experiences and information that institutions possess, as the process of applying and adopting knowledge management helps in achieving many positives and benefits; such as raising productivity, developing output quality, raising effectiveness and efficiency, solving administrative problems, making decisions, innovating and adapting to the vast number of increasing changes (Sera', 2014).

As the concepts of knowledge management and quality have become the main engine that enhances competition between institutions and individuals in the current era; knowledge management contributes to creating an important intellectual development concerned with employees with specializations, capabilities, and distinct abilities who practice knowledge activities and perform mental tasks in the institution (Madi, 2010).

\section{$1.1 \quad$ Research problem}

Although knowledge management and its applications are among the most central concepts that have seen a large spread in business enterprises, this concept has not received much interest from researchers and those interested in the field of management. In addition to that, many higher education organizations face many challenges, such as the low quality. Their failure to keep pace with the labor market requirements, the specializations taught in educational institutions no longer meet the labor market's needs, the labor market has become saturated with them, and this revolves around ensuring the quality of higher education. The effective use of current knowledge contributes to possessing the skills, technologies, and knowledge of the learner to raise its efficiency in creativity and production (Al-Baqour, 2016). Therefore, the current research revealed the reality of applying knowledge management practices and their impact on achieving the quality of higher education in the Hashemite Kingdom of Jordan. The problem of the current research is to answer the following questions:

\subsection{Research questions}

The present research seeks to answer the following central question:

- What is the reality of applying knowledge management practices and their impact on achieving higher education quality in Jordan?

A set of sub-questions emanate from the main question; Including the following:

- What is meant by the concept of knowledge management? What are knowledge management practices?

- What are the components of applying knowledge management in higher education institutions?

- What is meant by the quality of higher education? What are its standards and indicators? 


\subsection{The Research Aims}

The current research aims to identify the reality of applying knowledge management practices and reveal their impact on achieving the quality of higher education in Jordan, and the research objectives are represented in the following points:

- Learn the concept of knowledge management, and disclose knowledge management practices.

- Determine the components of applying knowledge management in higher education institutions.

- Knowing what is meant by the quality of higher education; and disclosure of its standards and indicators.

\subsection{The Research Importance}

The current research derives its importance from the importance of the topic it deals with, as the current study is based on revealing the reality of applying knowledge management practices, in addition to showing the extent of the impact of knowledge management and its practices on achieving the quality of higher education, and the importance of the research can be represented in the following points:

- To analyze the reality of applying knowledge management at Al-Balqa Applied University in Jordan.

- To provide a rich theoretical framework in the concepts and terminology related to the research title.

- To add a scientific addition that can be used in future studies and research.

- To Shed light on the relationship between knowledge management and the quality of higher education in Jordan.

\section{Methodology}

To achieve the research objectives and answer its questions, a descriptive and analytical approach was used that is compatible with the nature of the study. Previous studies and research were reviewed. A case study method has been adopted to obtain the data in question and shed light on the reality of applying knowledge management practices and their impact on achieving the quality of higher education at Al-Balqa Applied University in Jordan. Besides, a questionnaire tool has been prepared to reach the research results by analyzing the results that will be obtained through the questionnaire.

\section{Theoretical Framework and Previous Studies}

This part of the research was divided into three main parts related to knowledge management and the quality of higher education, followed by the part of previous studies and comments on them:

\subsection{First: Knowledge management}

To study knowledge management, one must learn about its concept, objectives, and practices:

\subsubsection{The concept of knowledge management}

Before dealing with the concept of knowledge management, the concept of knowledge must be recognized, as knowledge is defined as a mixture of values, information, and experiences possessed by individuals and institutions, as knowledge is an integral part of documents, practices, activities, and 
knowledge processes (Shamakhi, 2016).

Knowledge can be procedurally defined from the researcher's point of view as a set of ideas and experiences that a person possesses, and he seeks to use and apply them to develop himself and develop his practical outputs in the institution in which he works.

Knowledge management is defined as a set of activities and practices that institutions apply to spread and develop their knowledge, as well as the tools and processes that are used to achieve the highest levels of knowledge, expertise, intellectual capital, and other forms of knowledge, to employ and practice Knowledge exchange and learning (Taregn, 2017).

It can also be defined as the set of professional and cognitive capabilities that the institution possesses. It seeks to conduct its business in distinctive ways and at reduced costs, as it represents the expertise, knowledge, and technological technologies available within the institution (Al-Ziyadat, 2014).

According to Al-Khalidi and Al-Tahainah, knowledge management is one of the modern management concepts that have been born in some contemporary literature due to the technological and scientific development that the world is still witnessing in the current era in the field of knowledge and its transfer (Al-Tahaina and Al-Khalidi, 2015).

In light of this, knowledge management can be defined procedurally as an integrated set of administrative activities and practices that seek to define and develop knowledge in a way that contributes to improving performance efficiency, ensuring the continuity of the institution's development, and raising its ability to face the changes and address the problems it faces.

\subsubsection{Knowledge Management Practices}

Knowledge management practices are a group of processes that express the adoption of the concept of knowledge management, and there are a set of procedures or processes that are followed to achieve knowledge management, the most important of these are the following: (Aoun and Al-Hammoud, 2016)

- Knowledge Diagnosis: It is the process of identifying knowledge, as it constitutes the percentage of knowledge that is present in comparison with the knowledge that must be available to individuals.

- Knowledge Acquisition: It represents the process of obtaining knowledge from its primary and non-primary sources and working on crystallizing it into new, clear knowledge that can be used by everyone.

- Knowledge generation: It is the process of searching for, deriving, and using knowledge to contribute to improving and developing activities and practices carried out by individuals and institutions.

- Knowledge Storing: It represents the process of preserving knowledge and ensuring its continuity.

- Knowledge distributed: It is the process of transferring and exchanging knowledge between individuals.

\subsubsection{Knowledge Management Objectives}

Many institutions and organizations seek to apply knowledge management practices to achieve several goals, the most important of which are the following: (Maher and Hussein, 2014)

1. Assist in developing discussions and procedures concerned with management and improving the infrastructure of the knowledge society.

2. Work to develop social, organizational, and cultural trends in knowledge management.

3. Strive to improve the economic, cultural, and social factors that motivate individuals to participate in knowledge management.

4. Increase the number of individuals who have significant knowledge experiences. 
5. Transfer and exchange of knowledge and experiences between individuals.

6. Improve the institution's knowledge strength in various fields and activities.

\subsection{Second: the quality of higher education}

\subsubsection{The concept of higher education quality}

Quality is defined as the characteristics and features that provide services that lead to achieving the implicit and stated goals. Quality is the conformity and suitability in the traits, qualities, and standards, as the quality is represented in the reactions provided by customers and beneficiaries of the services provided by the institution (Hammoud, 2015).

Quality in the field of higher education can be defined as the process of applying a set of educational standards necessary to improve the level of scientific output by members of the academic body in educational institutions (Shamakhi, 2016).

Some believe that the quality of the educational process is a system that educational institutions adopt and bears the responsibility of those in charge of the educational process in these institutions, as this system seeks to improve the academic level in them, and that by providing scientific and educational plans and strategies (Maher and Hussein, 2014)

\subsubsection{The objectives of the quality of higher education}

The quality process in the field of the educational process seeks to achieve several goals, the most important of which are the following:

- Interpretation of scientific basics.

- Raise the competitiveness of scientific institutions.

- Provide various research capabilities with a high level of efficiency.

- Provide educational institutions with experiences and knowledge that are interested in developing education in its various fields.

- To have continuous development of all educational activities in the institution.

\subsubsection{The importance of higher education quality}

The importance of quality in the field of higher education can be represented by a set of points, as follows: (Harnan, 2014)

- It contributes to the detection of aspects of quality in the field of education and mental energies.

- Work to develop the quality of educational and non-educational services in educational institutions.

- Raise individuals' confidence within the educational institution and enhance the commitment of all those in charge of the educational process and those responsible for it in the educational institution.

- Contribute to institutional decision-making.

\subsection{Third: Previous Studies}

Many previous studies have shared some of their objectives with the current research; the following are the most recent:

The Sheikh's study (2018) titled "Diagnosing the Reality of Knowledge Management Application: An Exploratory Study of the Views of a Sample of the Teaching Staff in a Number of Economics and Administrative Sciences Faculties in Sudanese Universities" where the study aimed to study the reality 
of applying knowledge management processes in the Faculties of Economics and Administrative Sciences in Sudanese universities, to achieve this, the descriptive approach was used, in addition to preparing a questionnaire tool that was distributed to a sample of (136) faculty members from private and public universities in Sudan, the results confirmed that the application of knowledge management in universities in Sudan was of a low degree, and the results also showed that there are no statistically significant differences between the study sample individuals in relation to the reality of applying knowledge management in the universities of the study sample due to the variables of gender, years of experience, and the scientific degree.

Shamakhi study (2016) entitled "The role of knowledge management in ensuring the quality of higher education: a study of the sample of the Faculty of Economic Sciences, Commercial Sciences and Management Sciences - University of Qasidi Merbah and Ouargla" and which aimed to reveal the role of knowledge management in achieving the quality of the educational process in higher education institutions, to achieve the objectives of the study, the descriptive approach and the inductive approach were used, in addition to the questionnaire tool that was distributed to a sample of (50) professors working in the College of Economic and Commercial Sciences and Management Sciences who were deliberately chosen, the results of the study confirmed that there is a statistically significant relationship between modern scientific requirements and the quality of higher education, in addition to that, the results showed that there are no statistically significant differences attributable to the personal qualifications variable of the study sample individuals with regard to the quality of higher education.

The study of Al-Zaboon and the Sheikh (2015), which was entitled "The reality of knowledge management in private Jordanian universities from the viewpoint of faculty members and its relationship to some variables" where the study aimed to reveal the reality of knowledge management from the point of view of faculty members in private Jordanian universities, to achieve the objectives of the study, the descriptive and analytical method was used, in addition to preparing a questionnaire tool that was distributed to a randomly selected sample of (695), the results of the study confirmed that there are statistically significant differences between males and females at the level of significance (o.05) due to the gender variable in response to the reality of knowledge management in private universities, the results also showed that the fact of applying knowledge management came to an arithmetic average of (3.55) in the private Jordanian universities, and in light of the findings of the study, the two researchers recommended the need to pay attention to university leaders who are interested in improving and developing managerial practices.

Sera' study (2014) titled "Knowledge Management and its Role in Achieving Quality of Higher Education: A Case Study of the College of Economic Sciences, Business Sciences and Management Sciences - University of Arabia Bin Mahidi Umm El Bouaghi"which aimed to reveal the extent of applying knowledge management practices in one of the colleges of The Arab University, in addition to revealing the effect of their application on achieving the quality of education on the study sample, and to achieve the objectives of the study, a descriptive approach was used that suits the nature of the study, the study was applied to a sample of (79) professors working in the Faculty of Economic Sciences, Commercial Sciences and Management Sciences at Al-Arabi Bin Mahidi University, where the results showed that knowledge management is one of the administrative terms and approaches that are concerned with the optimal use of knowledge in both its explicit and implicit sides, and the results also showed that knowledge management positively affects the quality of the educational process.

\section{$3 \cdot 4$}

\section{Commenting on previous studies}

Although the previous studies that were listed above shared some aspects with the current research, they differed in some others, as the current research agreed in its objective with the Shamakhi study (2016) and Sera' study (2014), they aimed to uncover the role of knowledge management in achieving higher education quality. Still, despite sharing the goal, it differed in the community that was studied, as for the study of Al-Zaboon and the Sheikh (2015), it aimed to reveal the reality of knowledge management from the faculty's viewpoint members. While the study of the Sheikh (2018) aimed to 
study the reality of applying knowledge management processes in the Faculties of Economics and Administrative Sciences in Sudanese universities, to achieve the objectives of the current research, a descriptive and analytical approach was used that is compatible with the nature of the research, and this is consistent with the study of Al-Zaboon and the Sheikh (2015). As for the study of Sera' (2014) and the study of the Sheikh (2018), they used the descriptive method, while the study of Shamakhi (2016) used the descriptive and inductive approach to achieve its goals.

\section{Characteristics of the Study Sample}

The study sample consisted of (142) workers and those in charge of the educational process at Al-Balqa Applied University, who were randomly selected, and the tables below show a description of the study sample according to the variables (gender, age, academic qualification, job rank, years of experience):

\subsection{Gender variable}

Table 1: Distribution of the research sample according to the gender variable

\begin{tabular}{lcc} 
Gender & N & Percentage \\
\hline Male & 96 & 67.6 \\
Female & 46 & 32.4 \\
Total & 142 & 100.0
\end{tabular}

Table (1) shows the distribution of the sample members according to the gender variable; it appears that males are the most frequent, which reached (96) with a percentage of (67.6\%). In contrast, females are the least frequent, which reached (46) with a ratio of $(32.4 \%)$, which indicates that most of the study sample were males.

\subsection{Age variable}

Table 2: Distribution of the study sample according to the age variable

\begin{tabular}{lcc} 
Category & N & Percentage \\
\hline Less than 30 years old & 32 & 22.5 \\
From 30 to 50 years old & 56 & 39.4 \\
From 50 to 6o years old & 33 & 23.2 \\
Over 6o years old & 21 & 14.8 \\
Total & 142 & 100.0
\end{tabular}

Table (2) shows that the most prominent occurrence of the age variable reached (65) for the category (from 30-50 years) with a percentage of (39.4\%), followed by the category (from 50-60 years) with a frequency of (33) and with a percentage of $(23.2 \%)$ While the group greater than 6o years is the least frequent, which reached (21) with a percentage of (14.8\%).

\subsection{Academic qualification variable}

Table 3: Distribution of the study sample according to the academic qualification variable

\begin{tabular}{lcc} 
Scientific qualification & N & Percentage \\
\hline Bachelor & 17 & 12.0 \\
M.A. & 74 & 52.1 \\
Ph.D. & 51 & 35.9 \\
\hline Total & 142 & 100.0
\end{tabular}


Table (3) shows the distribution of the sample members according to the educational qualification variable. It appears that the sample members who have a master's qualification are the most frequent ones, which reached (74) with a percentage of (52.1\%). Then came the doctoral degree by a percentage of $(35.9 \%)$, while the respondents with a bachelor's degree were the least frequent, which amounted to (17) with a percentage of $(12 \%)$; this indicates that the majority of the study sample have high qualifications.

\subsection{Years of experience variable}

Table 4: Distribution of the study sample according to the years of experience variable

\begin{tabular}{lcc} 
Category & N & Percentage \\
\hline Less than five years & 42 & 29.6 \\
From 5 to 1o years & 60 & 42.3 \\
More than ten years & 40 & 28.2 \\
Total & 142 & 100.0
\end{tabular}

We notice from Table (4) that the most frequent occurrence of the years of experience variable for the category (5-10 years) is the most frequent, as it reached (6o) with a percentage of $(42.3 \%)$. Then the category (less than 5 years) came with a frequency of (42) and a percentage of $(29.6 \%)$, while the category (more than ten years) was the least frequent, which reached (40) and a percentage of (28.2\%), this indicates the great experience enjoyed by the majority of the sample members.

\subsection{Functional rank variable}

Table 5: Distribution of the study sample according to the variable functional rank

\begin{tabular}{lcc} 
Functional & Number & Percentage \\
\hline professor & 33 & 23.2 \\
Associate Professor & 60 & 42.3 \\
Assistant Professor & 49 & 34.5 \\
Total & $\mathbf{1 4 2}$ & $\mathbf{1 0 0 . 0}$
\end{tabular}

Table (5) shows the distribution of the sample members according to the Functional rank variable. It appears that the rank of associate professor is the most frequent, which reached (6o) by a percentage of $(42.3 \%)$, while the category of professor is the least frequent, which amounted to (33) with a percentage of $(23.2 \%)$.

\subsection{Tool Correction (The questionnaire)}

Likert quintet gradient scale was used (strongly agree, agree, neutral, disagree, strongly disagree) to measure the opinions of the subjects of the research sample, where weight was given to the answer to know the attitudes of the research sample members regarding the research questions, as the weights of the responses were classified as follows: Strongly disagree (1), disagree (2), neutral (3), agree (4), and strongly agree (5). The value of the arithmetic means was interpreted after its calculation based on the number of categories in the scale as follows:

Second: Calculating the length of the category by dividing the range by the number of categories, $4 / 5=0.80$, and thus the first category for the values of the arithmetic average are: from 1 to $1+0.8$, and the following table shows the values of the arithmetic averages and the interpretation of these values. 
Table 6: The values of arithmetic averages and their interpretation

Arithmetic mean values From 1 - 1.80

From 1.81 - 2.6o

From 2.61 - 3.40

From 3.41 - 4.20

From 4.21-5
Response criterion (Degree of approval)

Strongly Disagree

Disagree

Neutral

Agree

Strongly agree

\subsection{Search procedures}

The following procedures were followed to achieve the research objectives:

- Access to theoretical literature and previous studies related to the research topic.

- Prepare the search tool (the questionnaire).

- Determine the research population and its sample.

- Distribute the research tool to the sample individuals that amounted to (142) workers and those in charge of the educational process at Al-Balqa Applied University, and then collecting and checking it.

- Entering the data into the computer to perform the statistical processing of the data using the statistical packages program (SPSS) to reach the results.

- In light of the research findings, a set of recommendations were proposed.

\subsection{Statistical Treatment}

To answer the research questions, the statistical packages program (SPSS) was used to process the data after it was classified and entered into the computer through:

- The arithmetic means and standard deviations of the items of the search tool

- One-Sample T-test.

\section{Research Results}

This part included a presentation of the study results aimed at identifying the reality of applying knowledge management practices and their impact on achieving the quality of higher education in Jordan, identifying the components of applying knowledge management in higher education institutions, and revealing knowledge management practices. The results are presented below.

Findings related to answering the main question: What is the reality of applying knowledge management practices and their impact on achieving higher education quality in Jordan?

To answer this question, arithmetic averages and standard deviations were extracted for all paragraphs of the reality of applying knowledge management practices and their impact on achieving the quality of higher education in Jordan and the general average for the tool as a whole. The OneSample T. test was also applied to reveal knowledge management's effect on the quality of higher education. The tables below illustrate this. 


\subsection{Knowledge innovation and creativity}

Table 7: Arithmetic means and standard deviations for all knowledge and creativity innovation items $(\mathrm{n}=142)$

N Item

1 Knowledge management works to develop the creative vision of the employees at the university.

2 Knowledge management seeks to analyze the forms of knowledge available in the university

3 The university uses a variety of resources to create and generate knowledge.

4 Knowledge management contributes to narrowing the knowledge gap at the university.

5 Knowledge management encourages brainstorming to generate new ideas and uncover tacit knowledge.

6 Electronic methods and technologies are used to explore knowledge.

7 Within the university, employees interact with each other to generate knowledge and solve problems.

8 Knowledge management enhances employees' readiness and ability to receive knowledge and accept modern systems and employ them in their duties.

The overall average
Percentage

Mean STD Rank Level

\begin{tabular}{|c|c|c|c|c|c|c|c|c|}
\hline & & & & & & & & Leven \\
\hline Strongly & isagre & Jeutra & Agree & trongly & & & & \\
\hline Disagree & & & & agree & & & & \\
\hline 6.3 & 9.9 & 16.9 & 33.1 & 33.8 & 3.78 & 1.198 & 7 & $\begin{array}{c}\text { Strongly } \\
\text { agree }\end{array}$ \\
\hline 5.6 & 4.2 & 14.8 & 34.5 & 40.8 & 4.01 & 1.114 & 1 & $\begin{array}{c}\text { Strongly } \\
\text { agree }\end{array}$ \\
\hline 9.9 & 4.9 & 16.2 & 46.5 & 22.5 & 3.67 & 1.171 & 8 & Agree \\
\hline 4.2 & 4.2 & 16.2 & 52.1 & 23.2 & 3.86 & 0.965 & 6 & Agree \\
\hline 2.1 & 5.6 & 18.3 & 45.8 & 28.2 & 3.92 & 0.938 & 3 & Agree \\
\hline 3.5 & 3.5 & 16.2 & 43.7 & 33.1 & 3.99 & 0.978 & 2 & Agree \\
\hline 4.9 & 3.5 & 19.0 & 41.5 & 31.0 & 3.90 & 1.040 & 4 & Agree \\
\hline 5.6 & 3.5 & 16.2 & 45.8 & 28.9 & 3.89 & 1.046 & 5 & Agree \\
\hline
\end{tabular}

Table (7) shows that the arithmetic averages that measure knowledge innovation and creativity ranged between (3.67-4.01), the most prominent of which was paragraph No. (2) "Knowledge Management seeks to analyze the forms of knowledge available at the university." Then came Paragraph No. (6), "Electronic methods and techniques are used to explore knowledge," with an arithmetic average of (3.99), and to a level, Agree. The lowest arithmetic averages came for Paragraph No. (3): "The University adopts various sources for creating and generating knowledge," with an arithmetic average of (3.67) with a degree of I agree. The general average of knowledge innovation and creativity was (3.88) and a standard deviation (o.692). It also indicates that all the study sample individuals agree with the statements of this axis.

\subsection{Knowledge application}

Table 8: Arithmetic means and standard deviations for all knowledge application paragraphs ( $\mathrm{n}=142)$

N Item

Percentage

Mean STD Rank Level

Strongly Disagree Neutral Agree Strongly

disagree agree

1 The university seeks to apply the knowledge it possesses with a specialized team.

2 The University provides courses and training workshops for its employees regarding how to exploit forms of knowledge.

3 The university consults experts and specialists when applying knowledge.

4 The university seeks to overcome the obstacles that stand in the way of applying and employing knowledge.

5 The university conducted tests on the knowledge before applying it.

$\begin{array}{lllllllll}5.6 & 5.6 & 23.9 & 44.4 & 20.4 & 3.68 & 1.041 & 8 & \text { Agree } \\ 7.0 & 2.8 & 15.5 & 40.8 & 33.8 & 3.92 & 1.114 & 4 & \text { Agree } \\ & & & & & & & & \\ 1.4 & 6.3 & 15.5 & 43.0 & 33.8 & 4.01 & 0.938 & 1 & \text { Agree } \\ 2.1 & 4.2 & 16.2 & 49.3 & 28.2 & 3.97 & 0.899 & 3 & \text { Agree } \\ & & & & & & & & \\ 1.4 & 4.9 & 14.1 & 50.7 & 28.9 & 4.01 & 0.871 & 1 & \text { Agree }\end{array}$


coordinators are involved in the process of applying
knowledge.

Strongly Disagree Neutral Agree Strongly disagree agree

7 The university benefits from the expertise and knowledge of its employees.

8 The hall provides everything necessary to apply and employ the available knowledge.

Overall average

$\begin{array}{lrrrrrrrr}2.8 & 7.0 & 16.9 & 41.5 & 31.7 & 3.92 & 1.011 & 4 & \text { Agree } \\ & & & & & & & & \\ - & 7.0 & 23.9 & 40.9 & 28.2 & 3.90 & 0.894 & 7 & \text { Agree } \\ - & 8.5 & 18.3 & 45.8 & 27.5 & 3.92 & 0.892 & 4 & \text { Agree } \\ & & & & & 3.92 & 0.537 & & \end{array}$

Table (8) shows that the arithmetic averages that apply knowledge ranged between (3.68-4.01), the most prominent of which was for paragraphs No. (3), (5) "The university consults experts and specialists when applying knowledge." The university conducts tests on knowledge before applying it. " Respectively, then came Paragraph No. (4) "The university seeks to overcome the obstacles that stand in the way of applying and employing knowledge" with an arithmetic average of (3.97) and with a degree I agree, and the lowest arithmetic averages came for Paragraph No. (1) "The university seeks to apply the knowledge it possesses through a specialized work team "with an arithmetic average of (3.68) with a degree I agree. The general average of knowledge application was (3.92) and a standard deviation (o.537). It also indicates that all study sample individuals agree with the statements of this axis.

\subsection{Storage and distribution of knowledge}

Table 9: The arithmetic means and standard deviations for all knowledge storage and distribution items $(n=142)$

N Item

\begin{tabular}{ccccccccccc}
\multicolumn{4}{c}{ Percentage } & \multicolumn{9}{c}{ Mean STD Rank } & Level \\
$\begin{array}{c}\text { Strongly Disagree Neutral } \\
\text { disagree } \\
0.7\end{array}$ & 3.5 & 16.9 & 52.8 & $\begin{array}{c}\text { Agree Strongly } \\
\text { agree }\end{array}$ \\
2.1 & 5.6 & 12.7 & 47.9 & 31.7 & 4.01 & 0.930 & 5 & Agree \\
2.1 & 4.2 & 20.4 & 39.4 & 33.8 & 3.99 & 0.953 & 7 & Agree \\
2.8 & 3.5 & 14.1 & 43.0 & 36.6 & 4.07 & 0.950 & 4 & Agree \\
2.1 & 4.2 & 24.6 & 12.0 & 57.0 & 4.18 & 1.074 & 2 & $\begin{array}{c}\text { Strongly } \\
\text { agree }\end{array}$ \\
7.7 & 4.9 & 27.5 & 27.5 & 32.4 & 3.72 & 1.193 & 8 & $\begin{array}{c}\text { Strongly } \\
\text { agree }\end{array}$ \\
2.8 & 2.1 & 11.3 & 23.2 & 60.6 & 4.37 & 0.964 & 1 & $\begin{array}{c}\text { Strongly } \\
\text { agree }\end{array}$ \\
4.9 & 6.3 & 13.4 & 22.5 & 52.8 & 4.12 & 1.164 & 3 & $\begin{array}{c}\text { Strongly } \\
\text { agree }\end{array}$ \\
& & & & & & & & Agree \\
& & & & & & 4.06 & 0.494 & &
\end{tabular}

Table (9) shows that the arithmetic averages that measure the storage and distribution of knowledge ranged between (3.72-4.37), the most prominent of which was in paragraph No. (7) "The university has many methods and means used in preserving knowledge." Then came Paragraph No. (5) "The university relies on storing information and knowledge on archives and paper documents," with an arithmetic average (4.18) and to the level "strongly agree," and the lowest arithmetic averages came for Paragraph No. (6) "The university has a database equipped with information and knowledge in various fields." With a mean of 3.72, with a degree, I strongly agree. The general mean of knowledge storage and distribution was (4.06) and a standard deviation (0.494). It also indicates that all the study sample individuals agree with the statements of this axis. 


\subsection{The impact of knowledge management on the quality of higher education}

Table 1o: The arithmetic means and standard deviations for all paragraphs of the impact of knowledge management on the quality of higher education $(n=142)$

N Item

1 Information and knowledge can be obtained and collected from its sources within the university easily.

2 The university provides the best educational and knowledge curricula and programs.

3 The university provides knowledge services that contribute to the delivery of knowledge easily and simply.

4 The university enjoys accessible communication and interaction between employees and their affiliates.

5 The university seeks to take care of those in charge of the educational process and its workers and work to support them and develop their capabilities.

6 The university is making many efforts to modernize and develop its programs.

7 The university is interested in providing electronic services to its students and workers.

8 The university's internal and external services and activities' effectiveness in relation to knowledge and scientific research.

The overall average

Percentage Mean STD Rank Level

\begin{tabular}{|c|c|c|c|c|c|c|c|c|}
\hline \multicolumn{5}{|c|}{$\begin{array}{r}\text { Percentage } \\
\end{array}$} & \multirow{2}{*}{\multicolumn{2}{|c|}{ Mean SID }} & \multirow[t]{2}{*}{ Kank } & \multirow[t]{2}{*}{ Level } \\
\hline $\begin{array}{l}\text { Strongly } \\
\text { disagree }\end{array}$ & isagr & Jeutra & Agree & $\begin{array}{l}\text { trongly } \\
\text { agree }\end{array}$ & & & & \\
\hline 5.6 & 3.5 & 26.8 & 22.5 & 41.5 & 3.91 & 1.154 & 5 & $\begin{array}{c}\text { Strongly } \\
\text { agree }\end{array}$ \\
\hline 4.2 & 5.6 & 21.8 & 23.9 & $44 \cdot 4$ & 3.99 & 1.130 & 4 & $\begin{array}{c}\text { Strongly } \\
\text { agree }\end{array}$ \\
\hline $3 \cdot 5$ & 2.8 & $9 \cdot 9$ & 10.6 & 73.2 & 4.47 & 1.022 & 1 & $\begin{array}{c}\text { Strongly } \\
\text { agree }\end{array}$ \\
\hline 6.3 & 12.7 & 18.3 & 26.1 & 36.6 & $3 \cdot 74$ & 1.253 & 7 & $\begin{array}{c}\text { Strongly } \\
\text { agree }\end{array}$ \\
\hline 19.0 & 9.2 & 16.9 & 26.1 & 28.9 & $3 \cdot 37$ & 1.466 & 8 & $\begin{array}{c}\text { Strongly } \\
\text { agree }\end{array}$ \\
\hline 2.8 & 5.6 & 21.8 & 21.1 & 48.6 & 4.07 & 1.089 & 3 & $\begin{array}{c}\text { Strongly } \\
\text { agree }\end{array}$ \\
\hline 0.7 & 1.4 & $7 \cdot 7$ & 32.4 & $57 \cdot 7$ & 4.45 & 0.759 & 2 & $\begin{array}{c}\text { Strongly } \\
\text { agree }\end{array}$ \\
\hline 12.7 & 4.2 & 19.0 & 23.9 & 40.1 & $3 \cdot 75$ & 1.360 & 6 & $\begin{array}{c}\text { Strongly } \\
\text { agree }\end{array}$ \\
\hline
\end{tabular}

Table (10) shows that the arithmetic averages that measure the effect of knowledge management on the quality of higher education ranged between (3.37-4.47), the most prominent of which was for Paragraph No. (3) "The university provides cognitive services that contribute to the delivery of knowledge easily and simply." Then came Paragraph No. (7) "The university is interested in providing electronic services to its students and workers," with an arithmetic average of (4.45). The lowest arithmetic averages came for paragraph No. (5) "The university seeks to pay attention to those in charge of the educational process and its workers and to support and develop their capabilities" with an arithmetic average of (3.37), with a degree that I strongly agree.

The general average of knowledge management on the quality of higher education was (3.97) and a standard deviation (o.639). It also showed that all research sample members agree with the statements of this axis that indicate the effect of knowledge management on the quality of higher education.

Table 11: Results of applying the One-Sample t-test to the general average for measuring the impact of knowledge management on the quality of higher education

\begin{tabular}{ccccc} 
Mean & STD & T value & df & Sig \\
\hline 3.9674 & .63871 & 74.020 & 141 & .000
\end{tabular}

Table (11) shows that the value of (T) amounted to (74.020) and in statistical terms (o.ooo), where the general mean was compared with the standard value of the five-point grading, which is (3), the results showed an effect of knowledge management on the quality of higher education, which was statistically significant at the level of significance $(\alpha \leq 0.05)$. 


\section{Summary of the Study Results}

By presenting the results of the statistical analysis and answering the study questions, the study revealed that there is an impact of knowledge management on the quality of higher education, and the results were summarized as follows:

- The most critical knowledge innovation and creativity practices:

1. Knowledge management seeks to analyze the forms of knowledge available in the university.

2. Knowledge management encourages brainstorming to generate new ideas and uncover tacit knowledge.

3. Electronic methods and technologies are used to explore knowledge.

4. Within the university, employees interact with each other to generate knowledge and solve problems.

- Most crucial knowledge application practices:

1. The university consults with experts and specialists when applying knowledge.

2. The university seeks to overcome obstacles that stand in the way of applying and employing knowledge.

3. The university conducts knowledge tests before applying it.

- The most important practices for storing and distributing knowledge

1. The university is interested in distinguished employees and people with experience and knowledge.

2. The university relies on storing information and knowledge on archives and paper documents.

3. The university has many methods and means used to preserve knowledge.

4. The university forms unique and specialized committees to oversee the process of preserving and distributing knowledge.

- There is a presence of the knowledge management impact on the quality of higher education in the Balqa Applied University.

\section{Recommendations}

In light of the results reached, the research recommends the following:

1. Take care of those in charge of the educational process and its workers, supporting them, and developing their capabilities.

2. Work on communication and interaction between employees and their affiliates.

3. There is a need for the university to allow non-affiliates to benefit from its knowledge.

4. The university must have a database with information and knowledge in various fields.

5. Work to apply the knowledge you possess through a specialized work team.

6. The university must benefit from the experience and knowledge of its employees.

7. There is a necessity for the knowledge management to develop the university employees' creative vision.

8. Take into account the university's reliance on various sources to create and generate knowledge.

9. Conduct studies and research that examine the reality of applying knowledge management practices and their impact on achieving the quality of higher education to determine the level of these effects and avoid them.

10. Conducting such a study on a different sample in different regions and comparing the results of this study with the results of those studies to obtain a clearer picture of applying knowledge management practices and their impact on achieving the quality of higher education in Jordan. 


\section{References}

Al-Baqour, K. (2016). The Role of Information Technology and Knowledge Sharing and Their Impact in Achieving Quality Assurance in Higher Education - An Applied Study at Taif University. Studies Journal, Volume 43 (First Issue).

Al-Zaboon, M. \& Al-Sheikh, M. (2015). The reality of knowledge management in private Jordanian universities from the perspective of faculty members and their relationship to some variables. Journal of Studies for Educational Sciences, Volume 42 (2nd Issue).

Al-Ziyadat, M. (2014). Contemporary Trends in Knowledge Management (Second Edition). Amman, Jordan: Safaa House for Publishing and Distribution.

Aoun, W. \& Al-Hamoud, T. (2016). The role of quality practices in enhancing knowledge management processes in the College of Education at King Saud University from faculty members' viewpoint. Arab studies in education and psychology (number seventy-seventh).

Hammoud, K. (2015). Quality Management and Customer Service (Fourth Edition). The Hashemite Kingdom of Jordan: Al-Maseera House for Printing and Publishing.

Harnan, N. (2014). The contribution of knowledge management to improving the quality of higher education: a study of a sample of Algerian universities. University Mohamed Khoudir Biskra, specializing in managing organizations, the Republic of Algeria.

Madi, I. (2010). The role of knowledge management in ensuring the achievement of quality higher education "Case Study of the Islamic University of Gaza." Master thesis, Islamic University, Faculty of Commerce - Department of Business Administration, Palestine

Maher, A. \& Hussein, M. (2014). The impact of knowledge management processes on the quality of higher education in Iraq. Saudi International Conference.

Sera', T. (2014). Knowledge Management and its Role in Achieving Quality of Higher Education - Case Study of the College of Economic Sciences, Business Sciences, and Management Sciences. University of Elaraby Ben Mahidi Oum El Bouaghi, Faculty of Economic Sciences, Business Sciences and Management Sciences, Algeria.

Shamakhi, K. (2016). "The Role of Knowledge Management in Ensuring Achieving Quality of Higher Education: Study of the Sample of the College of Economic Sciences, Business Sciences and Management Sciences University of Qasidi Merbah and Ouargla." Master's thesis, Kassidi Merbah University - Ouargla, Faculty of Economic Sciences, Commercial Sciences, and Management Sciences.

Sheikh, B. (2018). Diagnosing the reality of applying knowledge management: an exploratory study of the opinions of a sample of the faculty in some economics and administrative sciences colleges in Sudanese universities. Najran University, College of Administrative Sciences - Department of Business Administration, Sudan.

Tahainah, Z. \& Al-Khalidi, H. (2015). Application of knowledge management in colleges of physical education in Jordanian universities. Journal of Studies for Educational Sciences, Volume 42 (2nd Issue).

Taregn, l. (2017). The role of knowledge management in enhancing organizational performance; the case of selected international NGOs operating in at Addis Ababa. Addis Ababa University, department of management, college of business, and economics. 